\title{
Study of Microplastics and Inorganic Contaminants in Mussels from the Montenegrin Coast, Adriatic Sea
}

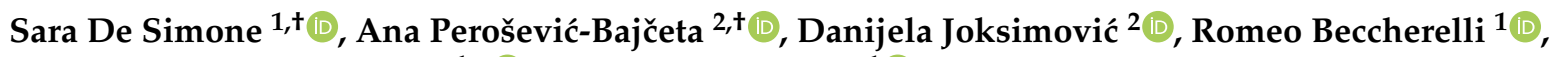 \\ Dimitrios C. Zografopoulos ${ }^{1, *(\mathbb{D})}$ and Valentina Mussi ${ }^{1}$ (D) \\ 1 Consiglio Nazionale delle Ricerche, Istituto per la Microelettronica e Microsistemi (CNR-IMM), \\ Via del Fosso del Cavaliere 100, 00133 Rome, Italy; sara.desimone@artov.imm.cnr.it (S.D.S.); \\ romeo.beccherelli@artov.imm.cnr.it (R.B.); valentina.mussi@cnr.it (V.M.) \\ 2 Institute of Marine Biology, University of Montenegro, Kotor 85330, Montenegro; anap@ucg.ac.me (A.P.-B.); \\ danijela.j@ucg.ac.me (D.J.) \\ * Correspondence: dimitrios.zografopoulos@artov.imm.cnr.it \\ + These authors contributed equally to this work.
}

check for updates

Citation: De Simone, S.;

Perošević-Bajčeta, A.; Joksimović, D.; Beccherelli, R.; Zografopoulos, D.C.;

Mussi, V. Microplastics and Inorganic Contaminants in Mussels from the Montenegrin Coast. J. Mar. Sci. Eng. 2021, 9, 544. https://doi.org/ 10.3390/jmse9050544

Academic Editors: Christina Zeri, Constantine Parinos and Elli Pitta

Received: 8 April 2021

Accepted: 16 May 2021

Published: 18 May 2021

Publisher's Note: MDPI stays neutral with regard to jurisdictional claims in published maps and institutional affiliations.

Copyright: (c) 2021 by the authors. Licensee MDPI, Basel, Switzerland. This article is an open access article distributed under the terms and conditions of the Creative Commons Attribution (CC BY) license (https:/ / creativecommons.org/licenses/by/ $4.0 /)$.

\begin{abstract}
Mussels (Mytilus galloprovincialis) collected at three locations in Boka Kotorska Bay, on the Montenegrin Adriatic coast, were analyzed for the first time by optical and Raman microscopy to detect microplastics (MPs) and other emerging contaminants in their soft tissues. Concentrations of six trace metals $(\mathrm{Cu}, \mathrm{Zn}, \mathrm{Mn}, \mathrm{Fe}, \mathrm{Cd}$, and $\mathrm{Hg}$ ) were also measured in the same samples by atomic absorption spectroscopy. Mussels from a location near the urban area of Kotor were found to exhibit the highest content of MPs and other pollutants originating from anthropogenic sources, while farmed mussels showed higher carotenoid as well as nylon content. The hypothesis of MPs acting as a possible secondary route of trace metals ingress in mussels, a thus far scarcely studied topic, was evaluated based on a comparative analysis of the obtained results. In this context, it was noticed that nylon filaments originating from mussel farming equipment might contribute to higher trace metal content. The results showed that the simultaneous analysis of different contaminants in mussels can be a significant step forward in marine environment pollution monitoring and the assessment of human health risks associated with the consumption of contaminated seafood.
\end{abstract}

Keywords: microplastics; emerging contaminants; trace metals; mussels; Raman spectroscopy

\section{Introduction}

Mussels (Mytilus spp.) are the most commonly used bioindicator species in marine pollution monitoring, with highly developed bioaccumulation ability [1-3]. As filter-feeding organisms, mussels accumulate a wide range of contaminants from their environment, including different trace metals, microplastics (MPs), pharmaceuticals, pesticides, and other sorts of emerging contaminants [4-10]. They are also known for their bioconcentration ability, since they cannot regulate individual concentrations of metals [11] or other pollutants, for instance, MPs [9]. Moreover, different harmful contaminants, such as persistent organic pollutants (POPs) and trace metals, can be adsorbed on the MPs hydrophobic surface, so that MPs ingestion can contribute to higher uptake levels of other contaminants as well $[8,12,13]$. Thus, to identify the mussel exposure routes to a specific pollutant, it is important to analyze all possible vectors of the pollutant's specific uptake in the mussel tissues. In this context, Raman spectroscopy offers a powerful approach to study samples dispersed in practically any matrix, liquid, gaseous or solid-state. It is a label-free, non-destructive analytical technique that provides information about molecular vibrations and structural fingerprints to identify the different elements composing the analyzed samples [14,15] and their degradation status, in a fast and reliable way [16].

In particular, Raman spectroscopy can be successfully used to identify and analyze different compounds in marine organisms. Indeed, analysis of MPs in mussels and other 
marine samples is increasingly performed using Raman spectroscopy alone or in combination with Fourier-transform infrared (FTIR) spectroscopy $[6,13,17]$. However, Raman analysis and imaging have some specific advantages with respect to FTIR spectroscopy, such as better spatial resolution, wider spectral coverage, narrower spectral bands, higher sensitivity to non-polar functional groups, and lower water interference. Among all these advantages, higher spatial resolution is probably of crucial importance when it comes to the detection of small MPs [18] with dimensions smaller than the IR wavelengths employed in FTIR.

To the best of our knowledge, this is the first study that investigates the presence of plastics and inorganic fragments and debris in mussels Mytilus galloprovincialis from the Montenegrin coast. The Raman results obtained for soft tissues of mussels collected from three different locations in Boka Kotorska Bay, on the Montenegrin Adriatic coast, are presented along with the results on trace metal concentrations $(\mathrm{Cu}, \mathrm{Zn}, \mathrm{Mn}, \mathrm{Fe}, \mathrm{Cd}$, and $\mathrm{Hg})$ in the same samples. Although trace metals have been regularly studied in mussels from the Montenegrin coast [19-23], the combination of data relating to diverse contaminants and obtained by means of different techniques can provide a much more general insight into the degree of environmental pollution from the ecotoxicological perspective, allowing also to identify possible secondary routes of trace metal uptake into mussel tissues. Since the production and human consumption of seafood are increasing worldwide [24,25], the presented analysis of contaminants in mussels and/or other marine organisms constitutes a fundamental step for public health risk assessment.

\section{Materials and Methods}

\subsection{Study Area}

Boka Kotorska Bay is a unique semi-enclosed bay in the southern part of the Adriatic Sea, along the Montenegrin coast. The bay is surrounded by high mountains and the sea deeply penetrates the continent, so the whole area is highly influenced by the land [26]. It consists of four smaller bays, Herceg Novi, Tivat, Risan, and Kotor Bay, which are connected by two straits [27]. This karst area is characterized by a high amount of precipitation and many freshwater tributaries, especially underwater springs, which are particularly present in Kotor and Risan Bay [26,28]. Therefore, Boka Kotorska is one of the areas with the highest inflow of fresh water in the South Adriatic, which affects the hydrographic properties of seawater in this area [29]. On the other hand, wastewater from some local sewage systems in the areas without adequate municipal system enters seawater, often untreated, which significantly affects its properties and contributes to pollution [30]. Additionally, trade and passenger ports, increasing marine traffic, ship repair facilities, aquaculture, and domestic and agricultural waste pose a threat to the marine life in this area [31].

Due to the overall characteristics of Boka Kotorska Bay, three distinct locations were selected for our research: Dobrota, Orahovac and Sveta Nedelja, see Figure 1. The first two locations are in Kotor Bay, relatively far from the open sea, and are greatly influenced by freshwater tributaries, as well as the mainland, since this part of the bay is an almost closed system, protected from sea currents. Therefore, there is a very low water exchange rate with the open sea [29]. Both locations are situated near populated places. The first sampling site, Dobrota (Institute of Marine Biology), is near the city of Kotor and its harbor, close to a very dense settlement. The second sampling site is a commercial fish and shellfish farm located near Orahovac, but not in the immediate vicinity of its populated part. The site Dobrota is characterized by the highest influence of municipal effluents and domestic waste, especially during summer tourist season, when there is a significant increase in population. Additionally, from early spring to late fall, large cruise ships enter the Harbor of Kotor daily. The third sampling site, Sveta Nedelja (Kamenari), refers to a mussel and oyster farm situated in Tivat Bay. Although it is not very close to a dense settlement, around $2 \mathrm{~km}$ far from this location there is a shipyard repair facility. Additionally, in the past, a military shipyard was in the town of Tivat. It is now replaced with a luxury marina, but the consequences of that specific industrial activity still highly influence the pollution level 
in Tivat Bay [31]. However, the location Sveta Nedelja is not so close to the town of Tivat and Tivat Bay is characterized by lower seawater dynamics, so the pollution from past industrial activities cannot be attributed to this location.

\subsection{Sample Collection and Preparation}

The sampling of mussels was conducted in spring 2020 at three different locations in Boka Kotorska Bay, Montenegro, at the Adriatic coast. To obtain representative samples, around $2 \mathrm{~kg}$ of mussels (Mytilus galloprovincialis) of similar shell length were collected at each sampling site. For transportation to the laboratory, mussels were placed into polyethylene bags with seawater. Once in the laboratory, mussels were cleaned and rinsed with Milli-Q water, and then the byssus and shells were removed. Soft tissues were frozen at $-18{ }^{\circ} \mathrm{C}$ and then freeze-dried at $-40{ }^{\circ} \mathrm{C}$ for $48 \mathrm{~h}$ (CHRIST, Alpha 2-4 LD plus). Afterwards, the freeze-dried samples were reduced to powder and homogenized.

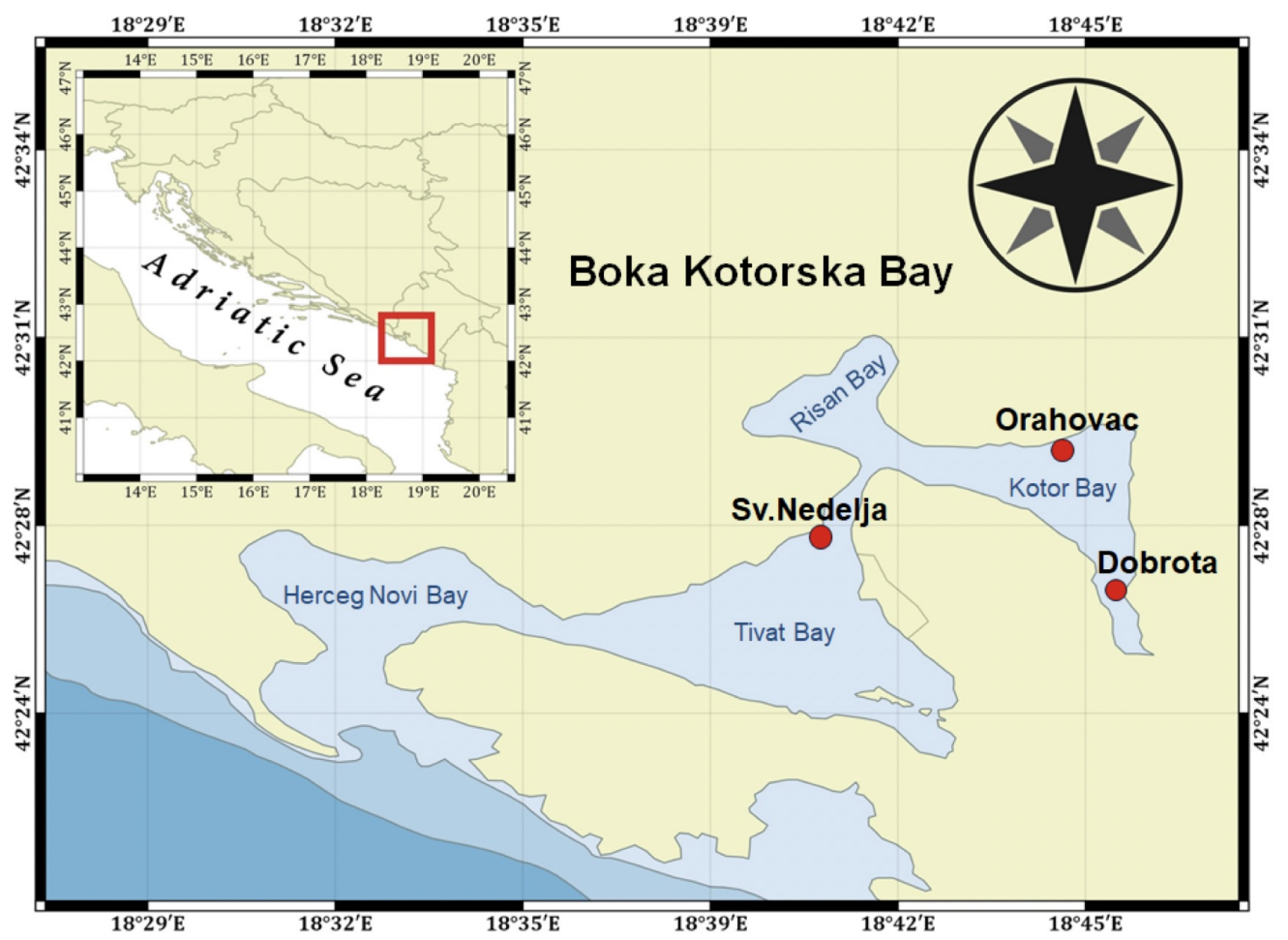

Figure 1. Map of Boka Kotorska Bay, Montenegro, showing the three locations where the investigated samples were collected.

\subsection{Raman Analysis}

Raman analysis was performed by means of a Thermo Scientific DXR2xi Raman Imaging Microscope through four consecutive preparation and measurement steps on the freeze-dried and pulverized mussel samples: (i) organic matter digestion, (ii) vacuum filtration, (iii) visual inspection of residues and debris, and (iv) spectral point or map acquisitions.

\subsubsection{Sample Digestion and Filtration}

The preparation of the samples for the Raman analysis required a procedure comprising several steps, as derived from the literature [32-35] and summarized for clarity in Figure 2. For each sample, $10 \mathrm{~g}$ of the corresponding powder (Figure 2A) were dispersed in $150 \mathrm{~mL}$ of $30 \% \mathrm{H}_{2} \mathrm{O}_{2}$ in the fume hood. The solution was then transferred to a glass beaker with a wide base to increase the evaporation surface during the successive digestion treatment in a ventilated oven for $48 \mathrm{~h}$ at $65^{\circ} \mathrm{C}$ (Figure $2 \mathrm{~B}$ ). Once all $\mathrm{H}_{2} \mathrm{O}_{2}$ was evaporated, a whitish solid foam/gelatinous precipitate was obtained (Figure $2 \mathrm{C}$ ). In the same glass 
beaker, $100 \mathrm{~mL}$ of concentrated saline solution $\left(250 \mathrm{~g} \mathrm{NaCl} / 1 \mathrm{H}_{2} \mathrm{O}\right.$ ) was added to dilute the precipitate (Figure $2 \mathrm{D}$ ). The solution was then magnetically stirred, alternating high speed cycles of 2-3 min with 3-6 min of rest, depending on the observed clearance rate of the suspension. Using a $10 \mathrm{~mL}$ pipette, the supernatant was extracted and transferred into a clean glass container (Figure 2E). The final solutions were vacuum filtered on $10 \times 10 \mathrm{~mm}^{2}$ micropored silicon membranes (Figure $2 \mathrm{G}$ ), characterized by thickness $50 \mu \mathrm{m}$, pore diameter $1 \mu \mathrm{m}$, and inter-pore distance $1.5 \mu \mathrm{m}$.

For each mussel sample originating from the three collecting locations (Dobrota, Orahovac and Sveta Nedelja), multiple membranes (3 to 6) were used to fully filter the dispersion, due to a high concentration of residues in the suspension, which gradually reduced the vacuum filtering efficiency and velocity. The digestion treatment used in this work eroded most of the different elements present in the initial powder. Hence, a generic organic background was found on the silicon surface together with some plastic/mineral solid particles, clusters, and filaments that, after optical localization and visual inspection, were spectrally characterized. Although the complexity of the overall protocol, composed of many subsequent steps, may reduce the effective number of recovered debris, the approach allows comparison of the level of contamination among different samples, and allows identification of the dimensions and typology of both organic and inorganic fragments or filaments.

The entire sample preparation protocol took place in class 1000 clean rooms (ISO 6), which guarantees a very low density of particles (lower than 300 parts $/ \mathrm{m}^{3}$ for particles larger than $5 \mu \mathrm{m}$ ). To further eliminate the chances of contamination of the samples with airborne particles from the ambient air, digestion and filtration were performed in a fume hood dedicated to this investigation. Before filtering, each silicon membrane was first inspected under optical microscope to ensure that the surface was clean. Figure 3A shows a visual image of the blank membrane and its periodic microstructure.

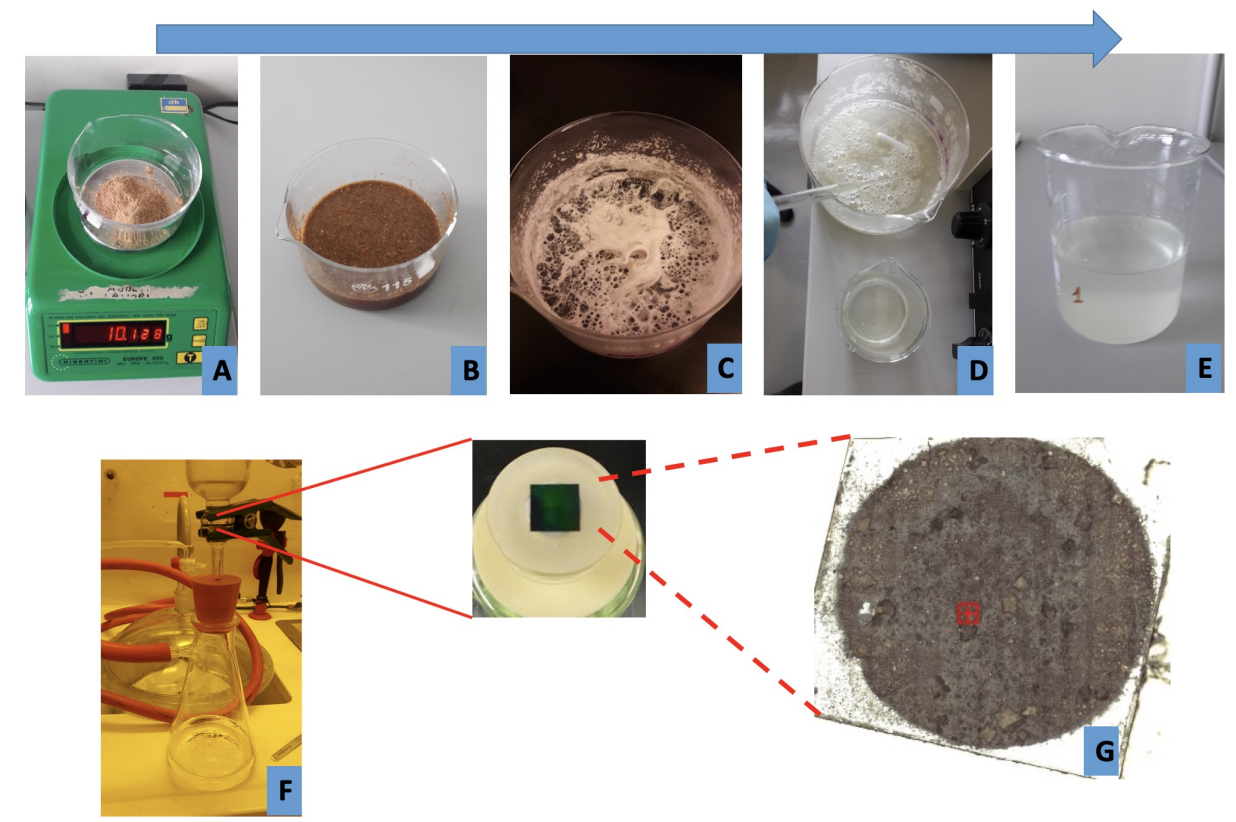

Figure 2. Preparation procedure of the samples for Raman analysis: the mussel powder (A) is dispersed in $30 \% \mathrm{H}_{2} \mathrm{O}_{2}$ (B) and subjected to a digestion treatment in a ventilated oven at $65{ }^{\circ} \mathrm{C}$. The resulting whitish precipitate (C) is diluted in a concentrated $\mathrm{NaCl}$ solution (D) and magnetically stirred to extract the supernatant (E), which is vacuum filtered on a micro-pored silicon membrane (F), used for microscopic and spectral investigation (G).

The implemented protocol is widely adopted for the study of MP in biological samples via Raman spectroscopy [17,18,32-35]. The efficiency of Raman investigation of bulk tissues is very low as it is hindered by the small penetration depth of the excitation beam and the 
strong background Raman signal of biological tissue, which can screen the weaker signals originating from MP or other contaminants. Both issues are alleviated by the chemical digestion and filtering of the samples. Furthermore, a primary focus of this work is the comparative study of the results originating from Raman and trace metal analysis, hence the same source material was used in both cases.

\subsubsection{Visual and Spectral Analysis}

The membranes were optically inspected and mapped with the microscope of the Raman apparatus using a $10 \times$ objective. The visual analysis allowed to identify large residues, smaller debris, filaments and clusters, whose images were collected and compared, obtaining color, shape, and dimension data, as well as an immediate information about each sample's overall contamination.

Once the interesting fragments were selected and localized, they were separately analyzed, collecting Raman point spectra and vibrational maps to better define their margins and borders. The spectra were measured by exciting the samples at $532 \mathrm{~nm}$ with 2 to $4 \mathrm{~mW}$ laser power, depending on the signal intensity and fragment nature. Each spectrum resulted from 200 to 400 accumulations of $100 \mathrm{~ms}$ acquisitions. The step size of the Raman maps was set at $1 \mu \mathrm{m}$. Figure 3B shows a typical Raman spectrum of the blank (bare) silicon microfilter. A single strong peak at $521 \mathrm{~cm}^{-1}$ is observed, which is a distinctive feature of bulk silicon stemming from the first-order optical phonon at the Brillouin-zone center. In the spectral window under investigation no other strong resonances manifest. Hence, the various Raman signal peaks observed in the filtered samples, as discussed in Section 3.1, do not originate from the silicon microfilter substrate.
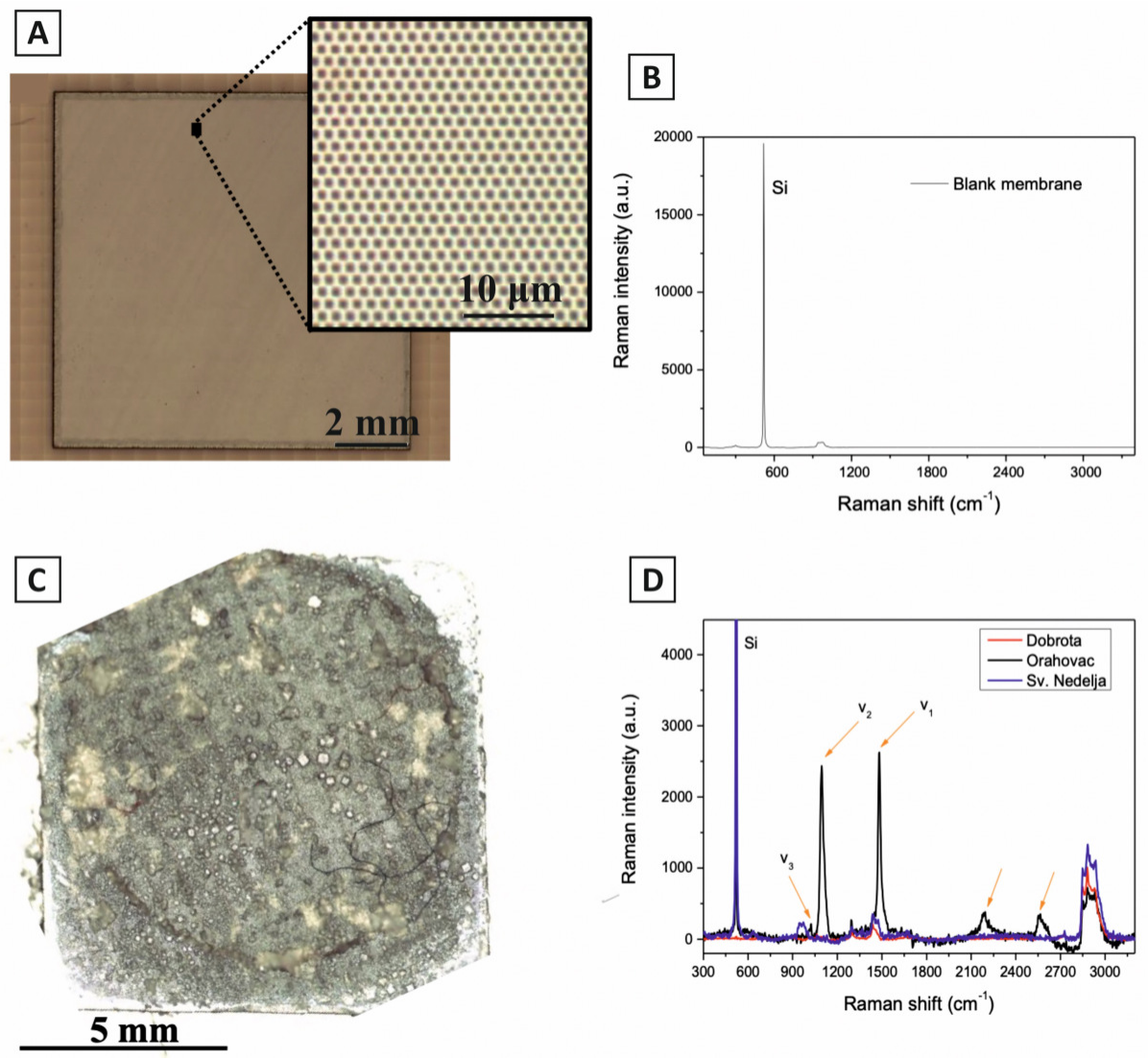

Figure 3. (A) Image of the blank silicon membrane and a zoomed image of its periodic microstructure (B) Raman spectrum of the blank silicon microfilter membrane. (C) Optical micrograph collected with a $10 \times$ objective of one of the membranes prepared from the Dobrota sample. (D) Spectra of the organic background present on the surface of the membranes realized by filtering samples from all three sampling locations. 


\subsection{Trace Metal Analysis}

For trace metal analysis, freeze-dried and powdered mussel samples were first digested, following a closed vessel microwave-assisted acid digestion procedure [36]. After that, the contents of six trace metals $(\mathrm{Cu}, \mathrm{Zn}, \mathrm{Mn}, \mathrm{Fe}, \mathrm{Cd}$, and $\mathrm{Hg}$ ) were determined by an atomic absorption spectrometer (AAS).

For the sample digestion under high temperature and pressure in a closed vessel microwave digestion system (Anton Paar, Multiwave PRO), $5 \mathrm{~mL}$ of $\mathrm{HNO}_{3}(>68 \%$, PrimarPlus-trace analysis grade, Fisher Chemical) and $2 \mathrm{~mL}$ of $\mathrm{H}_{2} \mathrm{O}_{2}(>30 \%$, analytical reagent grade, Fisher Chemical) were added to approximately $0.5 \mathrm{~g}$ of sample dry weight $(\mathrm{dw})$. The digested samples were transferred into polypropylene (PP) graduated tubes and diluted with Milli-Q water. For each batch of analysis, two blanks were prepared similarly as the samples.

Trace metal contents in mussel samples were determined by an AAS (AA 7000, Shimadzu). The concentrations of $\mathrm{Cu}, \mathrm{Zn}, \mathrm{Mn}, \mathrm{Fe}$, and $\mathrm{Cd}$ were determined using a flame technique, while a hydride technique of AAS was used for $\mathrm{Hg}$ content determination in the prepared mussel samples. To cross-check the accuracy of the applied analytical methods, the certified reference material NIST 2976 (mussel tissue) was also prepared and analyzed in the same manner, with each batch of samples. The recovery values observed for all the analyzed elements in the reported certified material ranged from $88 \%$ to $106.6 \%$. All results on trace element concentrations were recalculated using the obtained recovery values and expressed in milligrams per kilogram of sample dw.

\section{Results and Discussion}

\subsection{Raman Analysis}

Figure $3 C$ reports the optical micrograph collected with a $10 \times$ objective of one of the membranes prepared from the Dobrota sample. Some filaments and fragments can be recognized, immersed in an organic background whose Raman spectrum is reported in Figure 3D together with those similarly collected for the other two sampling locations. Some spectral features are common to all the acquired spectra, such as the peaks around $2900 \mathrm{~cm}^{-1}$, ascribed to C-H vibrations, and the intense contribution due to the underlying silicon substrate at $521 \mathrm{~cm}^{-1}$. However, certain specific bands, indicated by the arrows, appear only in the Orahovac sample and they are attributed to the presence of carotenoids [37]. In fact, the most intense band $\left(\mathrm{v}_{1}\right)$ at $1520 \mathrm{~cm}^{-1}$ comes from $\mathrm{C}=\mathrm{C}$ vibrations of the polyene chain, which depends on $\pi$-electron conjugation and molecular configuration, while the $\mathrm{v}_{2}$ band at about $1155 \mathrm{~cm}^{-1}$ is associated with C-C stretching coupled with C-C in-plane bending modes [38]. The $\mathrm{v}_{3}$ band around $1000 \mathrm{~cm}^{-1}$ can be also identified, stemming from the coupling of the in-plane rocking vibration of the methyl groups attached to the conjugation chain with the adjacent $\mathrm{C}-\mathrm{H}$ in-plane bending. The other two spectral components indicated by the arrows are assigned to the combinations $\mathrm{v}_{1}+\mathrm{v}_{3}\left(2300 \mathrm{~cm}^{-1}\right)$ and $\mathrm{v}_{1}+\mathrm{v}_{2}\left(2675 \mathrm{~cm}^{-1}\right)$. The presence of carotenoids, which is largely diffused in the Orahovac sample, is limited to a few localized clusters on the membranes prepared from the samples from Sveta Nedelja, while it was negligible on those obtained from the Dobrota sample. In fact, the presence of carotenoids in mussel samples has been widely discussed in the literature $[39,40]$ and the difference in the measured content has been ascribed to several reasons:

- Metabolic route (a diet containing microalgae that produces high quantities of carotenoids);

- Self-production in different phases of the breeding cycle;

- Different age;

- Different environmental stress due to the level of water immersion, depth of location during growth, sea currents.

The observed differences in the carotenoid content in the analyzed mussel samples, with the lowest content in those from Dobrota, are reasonable and to a certain extent expected since Dobrota is the furthest location from the open sea. It is situated in the 
enclosed and calm part of small Kotor Bay, protected from sea currents and waves. Thus, mussels from this location are probably exposed to lower environmental stress. In addition, at the location Sveta Nedelja there is a commercial shellfish farm, while at Orahovac there is a fish and shellfish farm, so that a higher carotenoid content in mussels can be due to increased daily food input and increased presence of organic matter, generating a higher phytoplankton content, particularly at the location of Orahovac. Mussels release ammonia in the water, and nitrogen compounds are essential for primary production. Moreover, the remineralization of organic matter from sediments is promoted by the deposition of mussel feces. Hence, although mussels use phytoplankton as food, at the same time they contribute to their growth [41,42].

Apart from the presence of carotenoids, many different solid residues were also identified in all the analyzed samples. Some of them appear as black or colored filaments, from tens of microns to some millimeters long. Figure $4 \mathrm{~A}-\mathrm{C}$ reports three different typologies of long filaments found on the membranes. Although the red ones generally tend to burn during laser irradiation and can be identified as cellulose fiber, rayon or viscose [43], the others show a clear Raman signal similar to the two reference spectra reported in Figure 4D,E, associable to nylon and polytetrafluoroethylene (PTFE).
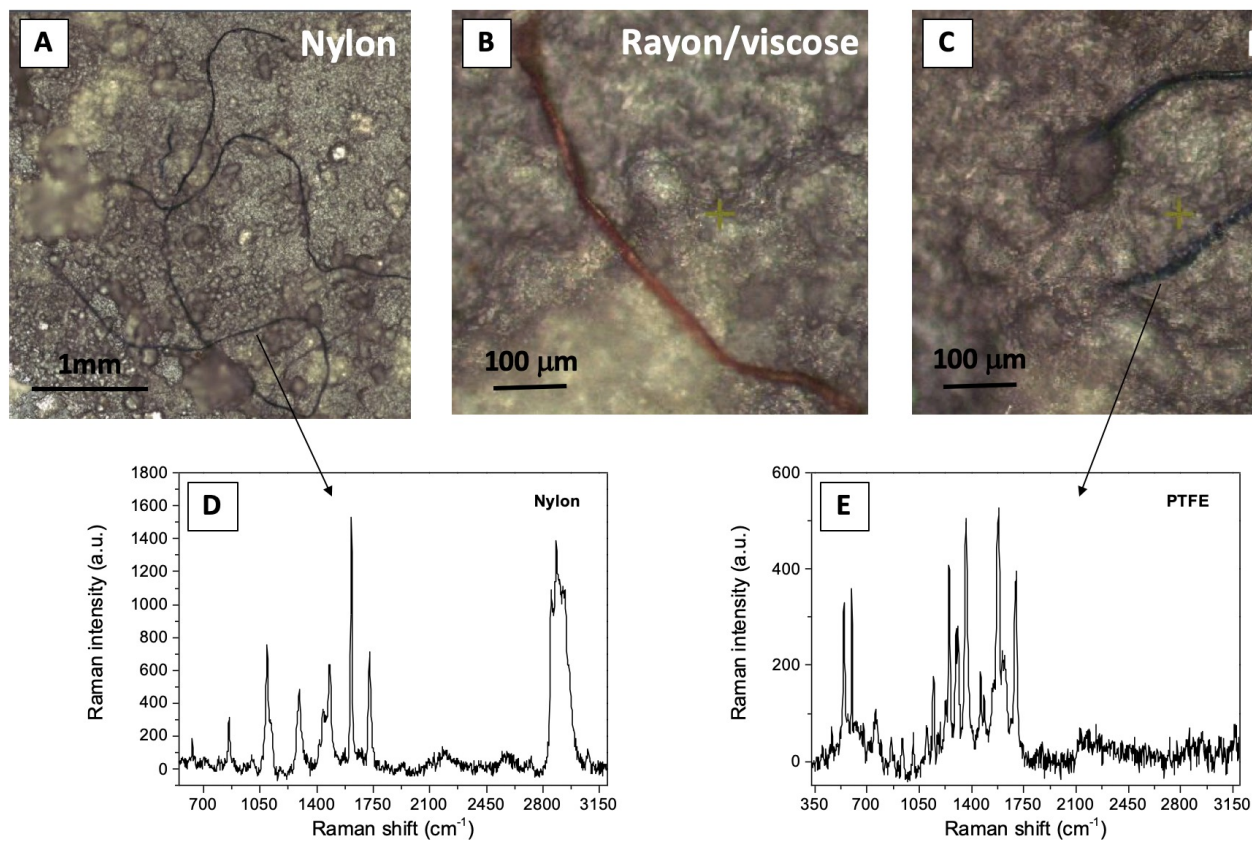

Figure 4. Optical images of different kinds of filaments found on the surface of the membranes and identified as: (A) nylon, (B) rayon/viscose, and (C) polytetrafluoroethylene. (D,E) Raman spectra for the two black filaments shown in $(\mathbf{A}, \mathbf{C})$.

Other kinds of debris were recognized on the surface of the various membranes and their Raman spectrum was compared with those reported in the literature and vibrational databases [18,43-47]. The comparison allowed to tentatively identify some of them as polymers, such as PP, polyethylene (PE), polyurethane (PU), polystyrene (PS) and acrylonitrile butadiene styrene (ABS). The attributions are made by taking into consideration that the acquired spectra are quite complex and contain many different contributions with respect to those tabulated for pure polymeric materials. In fact, the inspection of the Raman data as those shown in Figure 4 reveals that several different alterations both in peak intensities and positions manifest, due to degradation, digestion and oxidation processes. In particular, such modification processes of materials and matrices can cause enhancement or reduction of some spectral features with respect to others, so that the ratio between peak intensities can be also altered. However, the collected data provided sufficient information to attempt a reliable identification of the polymeric fragments that 
were found in different concentrations in all three mussel samples. Instead, some kinds of inorganic clusters were found only on specific membranes. Figure 5 shows images and the corresponding Raman spectra of $\mathrm{a} \mathrm{TiO}_{2}$ cluster and a graphite scrap that were detected in the Dobrota sample only.

The spectrum acquired from the $\mathrm{TiO}_{2}$ cluster and shown in Figure 5C, indicates that the material had a mixed phase. Indeed, the peaks located approximately at 392, 516 and $642 \mathrm{~cm}^{-1}$ can be attributed to characteristic vibrational frequencies of the anatase phase, while the features at 146 and $460 \mathrm{~cm}^{-1}$ correspond to stretching modes for the rutile phase $[48,49]$. As regards the small black splinter in Figure 5B, the high intensity of the disorder induced Raman band at $1370 \mathrm{~cm}^{-1}$ with respect to the peak at $1598 \mathrm{~cm}^{-1}$ reveals a graphitic nature with a relevant level of damage and impurities [50].
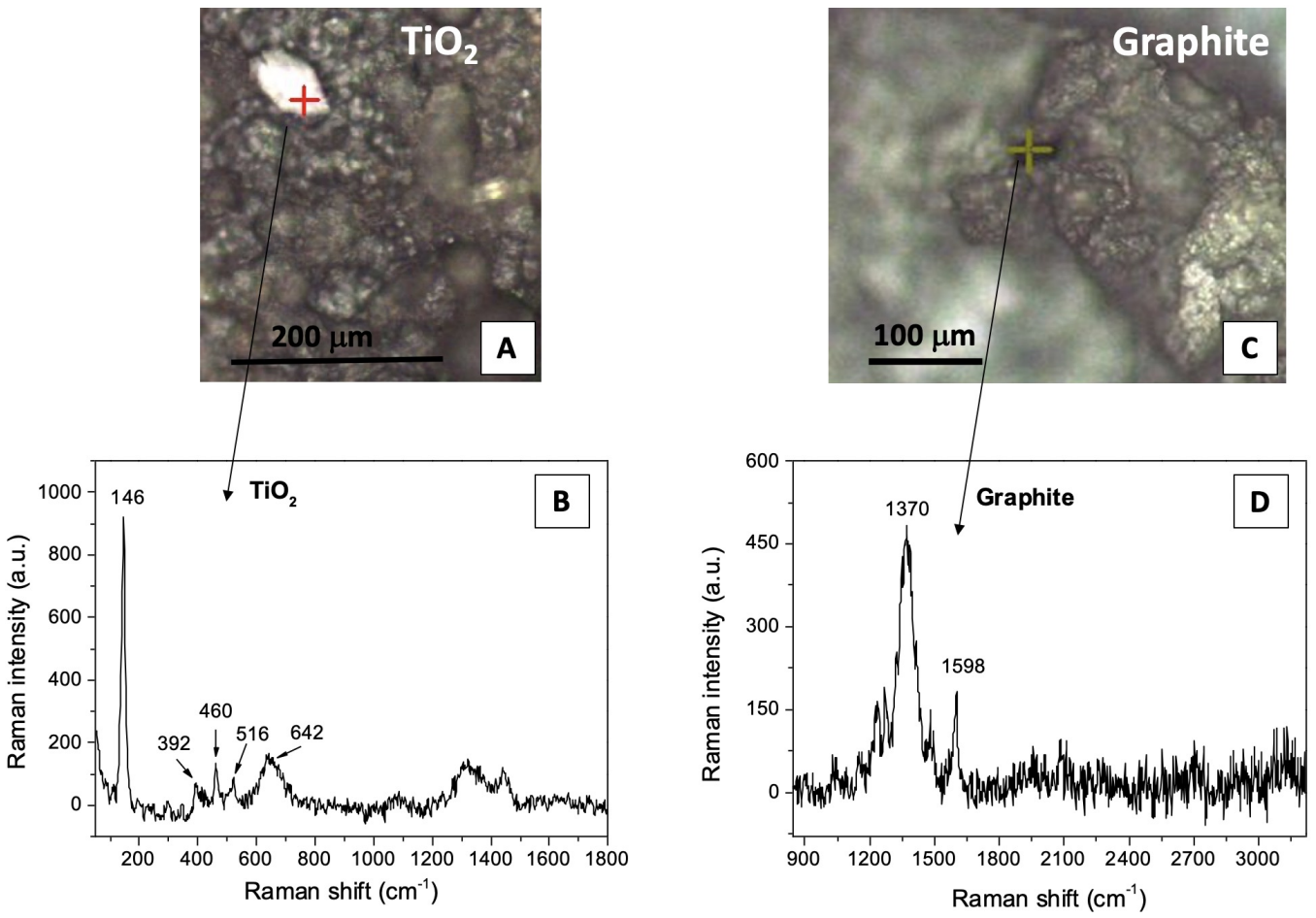

Figure 5. $(\mathbf{A}, \mathbf{B})$ Optical images of a $\mathrm{TiO}_{2}$ cluster and a graphite scrap, respectively, detected in the Dobrota sample only, and (C,D) corresponding Raman spectra.

Similarly, some kinds of fragments were found only in the Sveta Nedelja sample. In this case, clusters of aragonite were identified, as in Figure 6A, together with many and diffused small colored regions probably containing epoxy resin, one of which is shown in Figure 6C. Although it was not possible to collect a high-quality spectrum on the resin, the aragonite was clearly identified thanks to the peaks at $1085 \mathrm{~cm}^{-1}\left(\mathrm{CO}_{3}{ }^{2-}\right.$ symmetric stretching), $704 \mathrm{~cm}^{-1}\left(\mathrm{CO}_{3}{ }^{2-}\right.$ antisymmetric bending vibration), $206 \mathrm{~cm}^{-1}$ and $153 \mathrm{~cm}^{-1}$ (translational and rotational ion modes), all clearly visible in the measured spectrum reported in Figure 6B [51,52].

A synthesis of the visual and Raman analysis results is presented in Table 1. For each digested and filtered sample (first column), clear (second column) and attempted (third column) identifications of fragments, clusters and filaments present on the surface of the obtained membranes are reported. Some quantitative information is also given, to ease the comparison among the three samples. 


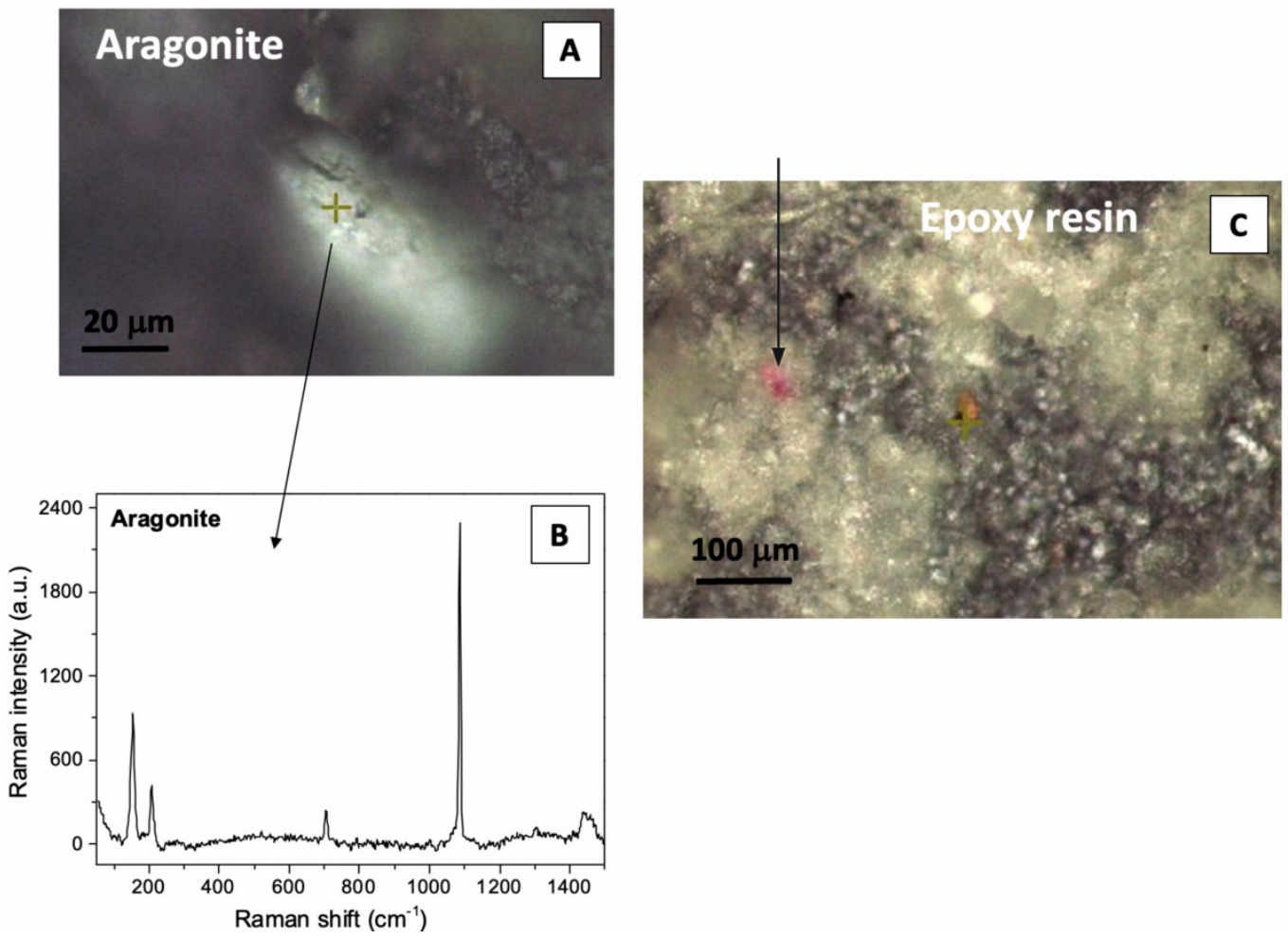

Figure 6. (A) Optical image and (B) corresponding Raman spectrum of an aragonite cluster. (C) Optical image of one of the many and diffused small regions containing epoxy resin bisphenol A (red spot). Both types of debris were found only in the Sveta Nedelja sample.

Table 1. Summary of the clear (central column) and attempted (last column) visual and Raman identifications of fragments, clusters and filaments on the surface of the membranes obtained by filtering the solutions resulting from sample digestion. The first column reports the collection location of the analyzed samples.

\begin{tabular}{ccc}
\hline Sample & Clear Identification & Attempted Identification \\
\hline \multirow{2}{*}{ Dobrota } & Nylon (at least one long filament) & Few PP/PE \\
\cline { 2 - 3 } & $\mathrm{TiO}_{2}$ & Few PU/PE \\
\cline { 2 - 3 } & Graphitic debris & Few PS/ABS \\
\cline { 2 - 3 } Sveta Nedelja & Fylon (at least 8 long filaments) & Several viscose/rayon (red filaments) \\
\cline { 2 - 3 } & Rich in carotenoids & Few PS/ABS \\
\cline { 2 - 3 } & Aragonite & Epoxy resin bisphenol A (diffused) \\
\hline \multirow{2}{*}{ Orahovac } & Carotenoids (diffused) & Few viscose/rayon (red filaments) \\
\cline { 2 - 3 } & Nylon (at least 2 long filaments) & Few PTFE \\
\hline
\end{tabular}

PP: polypropylene; PE: polyethylene; PU: polyurethane; PS: polystyrene; ABS: acrylonitrile butadiene styrene; PTFE: polytetrafluoroethylene.

To summarize, mussels from the location Dobrota were apparently the most contaminated by microplastics and textile fibers (viscose/rayon), mainly coming from urban discharges, and other pollutants, such as titanium dioxide microparticles, widely used in a variety of products including cosmetics, pharmaceuticals and detergents [53]. Conversely, the samples from Orahovac and Sveta Nedelja were characterized by high contents of carotenoids, probably since they derive from mussel farming. Nylon filaments were found in all analyzed samples, with the highest content in the mussels from Sveta Nedelja. This 
finding can be attributed to the high amount of nylon ropes and nets typically used in mussel farming [54,55].

There are very few published studies related to MPs in mussels Mytilus galloprovincialis from the Adriatic Sea or even from the Mediterranean. However, one study for Northern and Central Adriatic reported that the most common polymer type in Mytilus galloprovincialis from that region was PE, followed by PP, polyethylene terephthalate (PET), and equal amounts of PS, polyamide (PA), i.e., nylon, and polyvinyl chloride (PVC) [56]. In addition, Digka et al. [8] found that PE was the predominant type of MPs in mussels from the Northern Ionian Sea, while PP and PTFE were identified in equal amounts (12.5\% of detected plastics each). All these data are in good agreement with the Raman analysis results here reported.

\subsection{Trace Metal Contents}

Table 2 presents the results on the trace metal contents found in the analyzed mussel samples. The lowest concentration of four out of six analyzed elements, namely $\mathrm{Fe}, \mathrm{Zn}$, $\mathrm{Cd}$, and $\mathrm{Hg}$, was found in mussel samples from the location Dobrota. On the other hand, the highest contents of $\mathrm{Fe}, \mathrm{Zn}, \mathrm{Cd}$, and $\mathrm{Hg}$ were found in mussel samples from the location Sveta Nedelja, while the highest contents of $\mathrm{Mn}$ and $\mathrm{Cu}$ were found in mussels from the location Orahovac. However, the revealed differences appear minimal. At first sight, these results indicate that there might be no evident connection between trace metal contents and MPs found in the same mussel samples, since the mussels from the location Dobrota were characterized by the highest MPs content, see Table 1. Similarly, the study by Vieira et al. [57] did not demonstrate a direct relationship between MPs and metals in oysters from Paranaguá estuarine system in Brazil, suggesting that MPs cannot be considered to be a main route for metal contamination of oysters.

Nevertheless, given that a higher number of nylon residues was revealed by Raman mapping in Sveta Nedelja and Orahovac samples (see Table 1), most probably stemming from the nylon ropes and nets used in mussel farming, it is worth examining the hypothesis that nylon filaments (especially at the location Sveta Nedelja) could contribute to increased trace metal contents in mussels. This assumption could be supported by the higher metal sorption capacity of nylon than that of other MPs found in mussels from the examined locations, especially from the location Dobrota. Indeed, such a higher metal sorption capacity of PA in contrast to other MPs was observed in different laboratory experiments [58,59]. In particular, the investigation of sorption capacities of various MPs has shown that PA had higher Cd sorption capacity, compared to PVC, PS, ABS, and PET, [58] and higher Cu sorption capacity, compared to PE, PS, PET, and PVC [59].

Table 2. Trace metal concentrations ( $\mathrm{mg} / \mathrm{kg} \mathrm{dw}$ ) found in mussels Mytilus galloprovincialis at three locations from Boka Kotorska Bay.

\begin{tabular}{cccc}
\hline Element & Dobrota & Orahovac & Sveta Nedelja \\
\hline Fe & 110 & 129 & 141 \\
$\mathbf{Z n}$ & 70.7 & 75.3 & 81.0 \\
$\mathbf{M n}$ & 5.94 & 6.75 & 5.65 \\
$\mathbf{C u}$ & 5.93 & 6.37 & 5.17 \\
$\mathbf{C d}$ & 0.62 & 0.90 & 1.07 \\
$\mathbf{H g}$ & 0.084 & 0.110 & 0.122 \\
\hline
\end{tabular}

Although plausible, further studies, which would include different sampling seasons, are needed to fully corroborate this hypothesis. Additionally, the analysis revealed a moderate level of variability of the trace metal contents among the three locations, as well as various types of MPs, which could, in principle, act as metal vectors. With respect to the latter point, various authors studied the relationship between trace metal contents and MPs in mussels and other bivalves, and concluded that MPs could act as metal ingress vectors $[13,60,61]$. However, some of them indicated that the entrance of $\mathrm{Hg}$ in mussels 
was facilitated due to the MPs, but the $\mathrm{Hg}$ elimination rate was also higher than in the case of other pathways [60,61]. Because of the organic nature of phytoplankton, metals associated with phytoplankton particles enter the digestive gland easier, where after the digestion, the adsorbed metals are released. On the other hand, MPs, being non-nutritive particles, might be rejected in the stomach before their ingress into the digestive gland [60]. Moreover, Fernández et al. [61] found that the sorption capacity of MPs was lower than that of phytoplankton. This could explain the higher metal contents found in mussels from the locations Orahovac and Sveta Nedelja compared with the mussels from the location Dobrota. Since mussels feed on phytoplankton, higher phytoplankton content at these locations is probably connected to the higher observed carotenoid content and slightly increased trace metal concentration as well. It should also be remarked, though, that the same authors concluded that the MP contribution to the metal entrance in mussels should not be neglected, especially because MPs floating on the sea surface can be loaded with a higher concentration of metals than the phytoplankton particles, found under the microlayer of the sea surface [60].

\section{Conclusions}

This work represents the first correlated experimental investigation of MPs, inorganic fragments and debris, as well as trace metal contents, using mussels Mytilus galloprovincialis from the Montenegrin coast as bioindicators. Furthermore, the hypothesis of MPs acting as a possible secondary route of trace metals ingress in mussels was evaluated based on the results of the combined analysis, which involved the measurement of trace metal contents via AAS and the identification of MPs and other contaminants by micro-Raman spectroscopy.

The results showed that mussels from the location nearest to a dense urban settlement (Dobrota), were characterized by the highest content of MPs and some other pollutants, such as $\mathrm{TiO}_{2}$, originating from anthropogenic sources. On the contrary, higher carotenoid content was found in farmed mussels from the locations with probably higher phytoplankton abundance (Orahovac and Sveta Nedelja). Larger nylon content was also found in the farmed mussels from the latter two locations, with the highest number of polymeric filaments detected in samples from Sveta Nedelja, most possibly due to high amount of nylon nets and ropes used in mussel farming. Furthermore, mussels collected from Orahovac and Sveta Nedelja were generally characterized by slightly higher trace metal concentrations compared to those from Dobrota.

The comparative analysis of the obtained results hints to the hypothesis that nylon filaments could potentially act as trace metal ingress vectors in mussels. This kind of information can be extracted thanks to the simultaneous analysis of multiple contaminants in mussel soft tissues, thus highlighting the advantages of the adopted techniques.

The proposed combined approach can be crucial for marine environment pollution monitoring, as it provides insight into important sources of trace metals in mussels and other seafood from the Montenegrin coast. Such insight may contribute to the estimation of human health risks associated with the consumption of mussels from this region. We envisage that the experimental approach discussed in this paper could be broadly adopted in further investigation campaigns for the assessment of the contamination at different locations where the economically valuable Mytilus galloprovincialis and other related species are farmed.

Author Contributions: Sample preparation, S.D.S. and A.P.-B.; Raman analysis, S.D.S. and V.M.; trace metal analysis, A.P.-B. and D.J.; writing — original draft preparation, S.D.S., A.P.-B. and V.M.; writing-review and editing, D.J., R.B., D.C.Z., and V.M.; supervision, D.J., R.B., D.C.Z., and V.M.; project administration, D.J. and D.C.Z.; funding acquisition, D.J. and D.C.Z. All authors have read and agreed to the published version of the manuscript.

Funding: This research has been realized in the framework of the bilateral project "Ultra-broadband spectroscopy for the detection of emerging contaminants in Boka Kotorska Bay", funded by the 
Italian National Research Council (CNR) and the Ministry of Education, Science, Culture and Sports of Montenegro.

Institutional Review Board Statement: All applicable international, national, and/or institutional guidelines for the care and use of animals were followed.

Data Availability Statement: The data that support the findings of this study are available from the authors upon reasonable request.

Conflicts of Interest: The authors declare no conflict of interest.

\section{References}

1. Beyer, J.; Green, N.W.; Brooks, S.; Allan, I.J.; Ruus, A.; Gomes, T.; Bråte, I.L.N.; Schøyen, M. Blue mussels (Mytilus edulis spp.) as sentinel organisms in coastal pollution monitoring: A review. Mar. Environ. Res. 2017, 130, 338-365. [CrossRef] [PubMed]

2. Bat, L.; Arıcı, E.; Öztekin, A.; Yardım, Ö.; Üstün, F. Use of the Mediterranean Mussel Mytilus galloprovincialis Lamarck, 1819 from Sinop Coasts of the Black Sea as Bio-monitor. Int. J. Mar. Sci. 2018, 8, 44-47. [CrossRef]

3. Knopf, B.; Fliedner, A.; Radermacher, G.; Rüdel, H.; Paulus, M.; Pirntke, U.; Koschorreck, J. Seasonal variability in metal and metalloid burdens of mussels: Using data from the German Environmental Specimen Bank to evaluate implications for long-term mussel monitoring programs. Environ. Sci. Eur. 2020, 32, 7. [CrossRef]

4. Guendouzi, Y.; Soualili, D.L.; Boulahdid, M.; Boudjellal, B. Biological indices and monitoring of trace metals in the mussel from the southwestern mediterranean (Algeria): Seasonal and geographical variations. Thalassas 2017, 34, 103-112. [CrossRef]

5. Yigit, M.; Celikkol, B.; Yilmaz, S.; Bulut, M.; Ozalp, B.; Dwyer, R.L.; Maita, M.; Kizilkaya, B.; Yigit, Ü.; Ergün, S.; et al. Bioaccumulation of trace metals in Mediterranean mussels (Mytilus galloprovincialis) from a fish farm with copper-alloy mesh pens and potential risk assessment. Hum. Ecol. Risk Assess. 2017, 24, 465-481. [CrossRef]

6. Kumar, B.N.V.; Löschel, L.A.; Imhof, H.K.; Löder, M.G.J.; Laforsch, C. Analysis of microplastics of a broad size range in commercially important mussels by combining FTIR and Raman spectroscopy approaches. Environ. Pollut. 2021, $269,116147$. [CrossRef]

7. Fernández, B.; Albentosa, M. Insights into the uptake, elimination and accumulation of microplastics in mussel. Environ. Pollut. 2019, 249, 321-329. [CrossRef] [PubMed]

8. Digka, N.; Tsangaris, C.; Torre, M.; Anastasopoulou, A.; Zeri, C. Microplastics in mussels and fish from the Northern Ionian Sea. Mar. Pollut. Bull. 2018, 135, 30-40. [CrossRef]

9. Mezzelani, M.; Fattorini, D.; Gorbi, S.; Nigro, M.; Regoli, F. Human pharmaceuticals in marine mussels: Evidence of sneaky environmental hazard along Italian coasts. Mar. Environ. Res. 2020, 162, 105137. [CrossRef]

10. Brooks, S.J.; Ruus, A.; Rundberget, J.T.; Kringstad, A.; Lillicrap, A. Bioaccumulation of selected veterinary medicinal products (VMPs) in the blue mussel (Mytilus edulis). Sci. Total Environ. 2019, 655, 1409-1419. [CrossRef]

11. Mejdoub, Z.; Zaid, Y.; Hmimid, F.; Kabine, M. Assessment of metals bioaccumulation and bioavailability in mussels Mytilus galloprovincialis exposed to outfalls pollution in coastal areas of Casablanca. J. Trace Elem. Med. Biol. 2018, 48, 30-37. [CrossRef]

12. Wright, S.L.; Kelly, F.J. Plastic and human mealth: A micro issue? Environ. Sci. Technol. 2017, 51, 6634-6647. [CrossRef] [PubMed]

13. Amelia, T.S.M.; Khalik, W.M.A.W.M.; Ong, M.C.; Shao, Y.T.; Pan, H.J.; Bhubalan, K. Marine microplastics as vectors of major ocean pollutants and its hazards to the marine ecosystem and humans. Prog. Earth Planet. Sci. 2021, 8, 12. [CrossRef]

14. Chirayil, C.J.; Abraham, J.; Mishra, R.K.; George, S.C.; Thomas, S. Instrumental techniques for the characterization of nanoparticles. In Thermal and Rheological Measurement Techniques for Nanomaterials Characterization; Elsevier: Amsterdam, The Netherlands, 2017; pp. 1-36. [CrossRef]

15. Azammi, A.M.N.; Ilyas, R.A.; Sapuan, S.M.; Ibrahim, R.; Atikah, M.S.N.; Asrofi, M.; Atiqah, A. Characterization studies of biopolymeric matrix and cellulose fibres based composites related to functionalized fibre-matrix interface. In Interfaces in Particle and Fibre Reinforced Composites; Elsevier: Amsterdam, The Netherlands, 2020; pp. 29-93. [CrossRef]

16. Das, R.S.; Agrawal, Y.K. Raman spectroscopy: Recent advancements, techniques and applications. Vib. Spectrosc. 2011, 57, 163-176. [CrossRef]

17. Hermabessiere, L.; Paul-Pont, I.; Cassone, A.L.; Himber, C.; Receveur, J.; Jezequel, R.; Rakwe, M.E.; Rinnert, E.; Rivière, G.; Lambert, C.; et al. Microplastic contamination and pollutant levels in mussels and cockles collected along the channel coasts. Environ. Pollut. 2019, 250, 807-819. [CrossRef] [PubMed]

18. Araujo, C.F.; Nolasco, M.M.; Ribeiro, A.M.P.; Ribeiro-Claro, P.J.A. Identification of microplastics using Raman spectroscopy: Latest developments and future prospects. Water Res. 2018, 142, 426-440. [CrossRef] [PubMed]

19. Joksimovic, D.; Stankovic, S. The trace metals accumulation in marine organisms of the southeastern Adriatic coast, Montenegro. J. Serbian Chem. Soc. 2012, 77, 105-117. [CrossRef]

20. Joksimović, D.; Castelli, A.; Mitrić, M.; Martinović, R.; Perošević, A.; Stanković, S. Marine chemistry of the Boka Kotorska Bay. In The Handbook of Environmental Chemistry; Springer International Publishing: Cham, Switzerland, 2016; pp. 89-115. [CrossRef]

21. Perošević, A.; Joksimović, D.; Đurović, D.; Milašević, I.; Radomirović, M.; Stanković, S. Human exposure to trace elements via consumption of mussels Mytilus galloprovincialis from Boka Kotorska Bay, Montenegro. J. Trace Elem. Med. Biol. 2018, 50, 554-559. [CrossRef] [PubMed] 
22. Perošević, A.; Pezo, L.; Joksimović, D.; Đurović, D.; Milašević, I.; Radomirović, M.; Stanković, S. The impacts of seawater physicochemical parameters and sediment metal contents on trace metal concentrations in mussels-A chemometric approach. Environ. Sci. Technol. 2018, 25, 28248-28263. [CrossRef]

23. Perošević-Bajčeta, A.; Joksimović, D.; Castelli, A.; Peković, M.; Stanković, S. Trace elements in mussels from Montenegrin coast: A risk for human health. In The Handbook of Environmental Chemistry; Springer: Berlin/Heidelberg, Germany, 2021. [CrossRef]

24. FAO. The State of World Fisheries and Aquaculture 2016. Contributing to Food Security and Nutrition for All; FAO: Rome, Italy, 2016.

25. OECD/FAO. OECD-FAO Agricultural Outlook 2020-2029; FAO, Rome/OECD Publishing: Paris, France, 2020. [CrossRef]

26. Mandić, S.; Radović, I.; Radović, D. Physical and Geographical Description of the Boka Kotorska Bay. In The Boka Kotorska Bay Environment. The Handbook of Environmental Chemistry; Springer International Publishing: Cham, Switzerland, 2016; Volume 54, pp. 43-67. [CrossRef]

27. Bortoluzzi, G.; Giglio, F.; Ligi, M.; Del Bianco, F.; Ferrante, V.; Gasperini, L.; Ravaioli, M. The seafloor geomorphology of Boka Kotorska Bay. In Proceedings of the IMEKO, International Conference on Metrology for The Sea, Naples, Italy, 11-13 October 2017; pp. 246-251.

28. Joksimović, D.; Djurović, M.; Semenov, A.V.; Zohn, I.S.; Kostianoy, A.G. (Eds.) Introduction. In The Boka Kotorska Bay Environment. The Handbook of Environmental Chemistry; Springer International Publishing: Cham, Switzerland, 2016; Volume 54, pp. 1-17. [CrossRef]

29. Bellafiore, D.; Guarnieri, A.; Grilli, F.; Penna, P.; Bortoluzzi, G.; Giglio, F.; Pinardi, N. Study of the hydrodynamical processes in the Boka Kotorska Bay with a finite element model. Dyn. Atmos. Oceans 2011, 52, 298-321. [CrossRef]

30. Da Ros, L.; Moschino, V.; Macic, V.; Schintu, M. An ecotoxicological approach for the Boka Kotorska Bay (south-eastern Adriatic Sea): First evaluation of lysosomal responses and metallothionein induction in mussels. Mar. Pollut. Bull. 2011, 63, 326-333. [CrossRef] [PubMed]

31. Joksimović, D.; Perošević, A.; Castelli, A.; Pestorić, B.; Šuković, D.; Đurović, D. Assessment of heavy metal pollution in surface sediments of the Montenegrin coast: A 10-year review. J. Soils Sediments 2020, 20, 2598-2607. [CrossRef]

32. Bessa, F.; Frias, J.; Kögel, T.; Lusher, A.; Andrade, J.; Antunes, J.C.; Sobral, P.; Pagter, E.; Nash, R.; O'Connor, I.; et al. Harmonized Protocol for Monitoring Microplastics in Biota; Deliverable 4.3; JPI-Oceans BASEMAN Project: Oostende, Belgium, 2019. [CrossRef]

33. Lusher, A.L.; Welden, N.A.; Sobral, P.; Cole, M. Sampling, isolating and identifying microplastics ingested by fish and invertebrates. Anal. Methods 2017, 9, 1346-1360. [CrossRef]

34. Mathalon, A.; Hill, P. Microplastic fibers in the intertidal ecosystem surrounding Halifax Harbor, Nova Scotia. Mar. Pollut. Bull. 2014, 81, 69-79. [CrossRef] [PubMed]

35. Thiele, C.J.; Hudson, M.D.; Russell, A.E. Evaluation of existing methods to extract microplastics from bivalve tissue: Adapted $\mathrm{KOH}$ digestion protocol improves filtration at single-digit pore size. Mar. Pollut. Bull. 2019, 142, 384-393. [CrossRef] [PubMed]

36. IAEA. Training Workshop on the Analysis of Trace Metals in Biological and Sediment Samples. Laboratory Procedure Book; International Atomic Energy Agency, Marine Environment Laboratory: Monaco, 2015. [CrossRef]

37. Gong, N.; Li, Z.; Sun, C.; Men, Z. External field effect on electronic and vibrational properties of carotenoids. In Progress in Carotenoid Research; InTech: London, UK, 2018. [CrossRef]

38. Macernis, M.; Galzerano, D.; Sulskus, J.; Kish, E.; Kim, Y.H.; Koo, S.; Valkunas, L.; Robert, B. Resonance Raman spectra of carotenoid molecules: Influence of methyl substitutions. J. Phys. Chem. A 2014, 119, 56-66. [CrossRef] [PubMed]

39. Bjerkeng, B.; Hertzberg, S.; Liaaen-Jensen, S. Carotenoids in food chain studies-V. Carotenoids of the bivalves Modiolus modiolus and Pecten maximus_Structural, metabolic and food chain aspects. Comp. Biochem. Physiol. B 1993, 106, 243-250. [CrossRef]

40. Petes, L.E.; Menge, B.A.; Harris, A.L. Intertidal mussels exhibit energetic trade-offs between reproduction and stress resistance. Ecol. Monogr. 2008, 78, 387-402. [CrossRef]

41. Suplicy, F.M. A review of the multiple benefits of mussel farming. Rev. Aquac. 2018, 12, 204-223. [CrossRef]

42. Tamburini, E.; Turolla, E.; Fano, E.A.; Castaldelli, G. Sustainability of mussel (Mytilus galloprovincialis) farming in the Po river delta, northern Italy, based on a life cycle assessment approach. Sustainability 2020, 12, 3814. [CrossRef]

43. Lusher, A.; Bråte, I.L.N.; Hurley, R.; Iversen, K.; Olsen, M. Testing of Methodology for Measuring Microplastics in Blue Mussels (Mytilus spp) and Sediments, and Recommendations for Future Monitoring of Microplastics (R \& D-Project); Technical Report; Norwegian Institute for Water Research: Oslo, Norway, 2017. [CrossRef]

44. Clunies-Ross, P.J.; Smith, G.P.S.; Gordon, K.C.; Gaw, S. Synthetic shorelines in New Zealand? Quantification and characterisation of microplastic pollution on Canterbury's coastlines. N. Z. J. Mar. Freshwater Res. 2016, 50, 317-325. [CrossRef]

45. Zhao, S.; Zhu, L.; Li, D. Microplastic in three urban estuaries, China. Environ. Pollut. 2015, 206, 597-604. [CrossRef] [PubMed]

46. Zhao, S.; Danley, M.; Ward, J.E.; Li, D.; Mincer, T.J. An approach for extraction, characterization and quantitation of microplastic in natural marine snow using Raman microscopy. Anal. Methods 2017, 9, 1470-1478. [CrossRef]

47. Lenz, R.; Enders, K.; Stedmon, C.A.; Mackenzie, D.M.A.; Nielsen, T.G. A critical assessment of visual identification of marine microplastic using Raman spectroscopy for analysis improvement. Mar. Pollut. Bull. 2015, 100, 82-91. [CrossRef] [PubMed]

48. Balachandran, U.; Eror, N.G. Raman spectra of titanium dioxide. J. Solid State Chem. 1982, 42, 276-282. [CrossRef]

49. Challagulla, S.; Tarafder, K.; Ganesan, R.; Roy, S. Structure sensitive photocatalytic reduction of nitroarenes over TiO 2 . Sci. Rep. 2017, 7, 8783. [CrossRef]

50. Tuinstra, F.; Koenig, J.L. Raman spectrum of graphite. J. Chem. Phys. 1970, 53, 1126-1130. [CrossRef] 
51. Pierre, M.D.L.; Carteret, C.; Maschio, L.; André, E.; Orlando, R.; Dovesi, R. The Raman spectrum of CaCO 3 polymorphs calcite and aragonite: A combined experimental and computational study. J. Chem. Phys. 2014, 140, 164509. [CrossRef]

52. Edwards, H.G.M.; Villar, S.E.J.; Jehlicka, J.; Munshi, T. FT-Raman spectroscopic study of calcium-rich and magnesium-rich carbonate minerals. Spectrochim. Acta A Mol. Biomol. Spectrosc. 2005, 61, 2273-2280. [CrossRef]

53. Dréno, B.; Alexis, A.; Chuberre, B.; Marinovich, M. Safety of titanium dioxide nanoparticles in cosmetics. J. Eur. Acad. Dermatol. Venereol. 2019, 33, 34-46. [CrossRef]

54. Jakate, G.M.; Singh, H.; Ranade, A.; Sawant, N.H.; Pathan, D.; Deolalikar, A.; Tibile, R.M. Effect of different substrata on the growth and survival of green mussel Perna viridis in raft culture at Ratnagiri (India). Asian Fish. Sci. 2009, 22, 561-567.

55. Laxmilatha, P.; Thomas, S.; Asokan, P.K.; Surendranathan, V.G.; Sivadasan, M.P.; Ramachandran, N.P. Mussel farming initiatives in north Kerala, India: A case of successful adoption of technology, leading to rural livelihood transformation. Aquac. Asia 2009, 14, 9-13.

56. Gomiero, A.; Strafella, P.; Øysæd, K.B.; Fabi, G. First occurrence and composition assessment of microplastics in native mussels collected from coastal and offshore areas of the northern and central Adriatic Sea. Environ. Sci. Technol. 2019, 26, 24407-24416. [CrossRef]

57. Vieira, K.S.; Neto, J.A.B.; Crapez, M.A.C.; Gaylarde, C.; Pierri, B.; Saldaña-Serrano, M.; Bainy, A.C.D.; Nogueira, D.J.; Fonseca, E.M. Occurrence of microplastics and heavy metals accumulation in native oysters Crassostrea Gasar in the Paranaguá estuarine system, Brazil. Mar. Pollut. Bull. 2021, 166, 112225. [CrossRef] [PubMed]

58. Zhou, Y.; Yang, Y.; Liu, G.; He, G.; Liu, W. Adsorption mechanism of cadmium on microplastics and their desorption behavior in sediment and gut environments: The roles of water $\mathrm{pH}$, lead ions, natural organic matter and phenanthrene. Water Res. 2020, 184, 116209. [CrossRef]

59. Yang, J.; Cang, L.; Sun, Q.; Dong, G.; Ata-Ul-Karim, S.T.; Zhou, D. Effects of soil environmental factors and UV aging on Cu ${ }^{2+}$ adsorption on microplastics. Environ. Sci. Pollut. Res. 2019, 26, 23027-23036. [CrossRef]

60. Rivera-Hernández, J.R.; Fernández, B.; Santos-Echeandia, J.; Garrido, S.; Morante, M.; Santos, P.; Albentosa, M. Biodynamics of mercury in mussel tissues as a function of exposure pathway: Natural vs microplastic routes. Sci. Total Environ. 2019, 674, 412-423. [CrossRef]

61. Fernández, B.; Santos-Echeandía, J.; Rivera-Hernández, J.R.; Garrido, S.; Albentosa, M. Mercury interactions with algal and plastic microparticles: Comparative role as vectors of metals for the mussel, Mytilus galloprovincialis. J. Hazard. Mater. 2020, 396, 122739. [CrossRef] [PubMed] 